\title{
Food Inflation and Passenger Vehicle Purchases in South Africa: Cointegration, Short Run Dynamics
} and Causality

\author{
Eric Kateta Tshiakambila, *Joseph Chisasa \\ Department of Finance, Risk Management and Banking, University of South Africa \\ erictshiakam@yahoo.fr, ${ }^{*}$ chisaj@unisa.ac.za
}

\begin{abstract}
Food inflation in South Africa has been observed to be a major source of underlying inflationary pressures in the economy due to its persistence beyond that of other commodities. In this regard, this study investigated whether an increase in the prices of food products has a significant effect on passenger vehicle purchases in South Africa. The Phillip-Perron (PP) test, showed vehicle purchases to be stationary in level while food inflation was stationary in the first difference. Using secondary time series data, the Johansen cointegration test revealed that the variables in the vehicle purchase function were cointegrated in the long run. The vector error correction model showed a long-run relationship, albeit insignificant, between food inflation and vehicle purchases. There was no evidence of a short run relationship between the two variables. The Granger causality test revealed no causal effect between the variables, regardless of the direction of the test. The study concluded that an increase in the prices of food products will not play a considerable role in consumers' vehicle purchase decisions in South Africa. These results have policy implications for the motor and related industries.
\end{abstract}

Keywords: Passenger vehicle purchases; Food inflation; Cointegration; Vector error correction model; Granger causality

\section{Introduction}

Inflation is considered as posing serious economic challenges to businesses and consumers. This is mainly due to its adverse effect on the value of consumer buying power, social instability and reduction of confidence in the currency (Ashraf, Gershman \& Howitt, 2013). It was observed that food prices in South Africa, have an indirect impact on inflation, through their effect on inflationary expectations, wages and the prices of other components in the consumer price index (CPI) (Rangasamy, 2010). The country is considered to have a larger weight for food items in its consumption basket; hence the increase of food prices has a large impact on inflation trends. Furthermore, food inflation in South Africa has been more persistent than the inflation of other commodities, thus considered as an important source of underlying inflationary pressures in the economy (Rangasamy, 2010). Considering that several studies have established a significant correlation between inflation and automobile sales (Apec, 2012; Chifurira, Mudhombo, Chikobvu, \& Dubihlela, 2014; McGowan, 1984; Muhammad, Hussin, Razak, Rambeli \& Tha, 2013; Muhammad, Hussin \& Razak, 2012; Zide, 2012), it is therefore important to seek to establish the possible existing link between food inflation and vehicle purchases in South Africa. Although several other studies also identified food to be one of the factors that influence purchase decisions (Cheng, Sims \& Teegen, 1997; Makatouni, 2002; Munchanda, Ansari \& Gupta, 1999; Pieterse, 2009; Rimal, Moon \& Balasubramanian, 2005), there appears to be an absence of research that directly links food inflation to passenger vehicle purchases.

The present study will attempt to cover that gap and contribute to the literature by seeking to establish a causal relationship between vehicle purchases and food inflation. It will furthermore, seek to investigate whether the two variables are cointegrated in the long run and have a short run relationship. A recent study by Chifurira et al. (2014) examined the impact of inflation on automobile sales in South Africa. The author found that inflation and new vehicle sales in South Africa are cointegrated in the long run, thus supporting the existence of a long-run equilibrium relationship between the two. Additionally, a one-way causal effect (unidirectional causality) was found, running from inflation to new vehicles sales at a $5 \%$ level of significance. With the aim of providing an answer to the question of whether the increase in prices of food products has a significant effect on passenger vehicle purchase decision in South Africa, the rest of this paper will be structured as follows. Section 2 presents a literature review. Section 3 discusses the data and methodology. Section 4 presents the results, while Section 5 concludes. 


\section{Literature Review}

Trends in passenger vehicle sales in South Africa: In South Africa, the 2008 global meltdown saw a decline in new passenger vehicle sales during 2009, with 258129 units being sold in comparison with the average of 416335 units sold per year over the four previous years (International Organisation of Motor Vehicle Manufacturers, 2014). However, new passenger vehicle sales recovered by $5.67 \%$ by December 2011 yearon-year, compared to the same period in the previous year, and reached 450440 units sold in 2013 (International Organisation of Motor Vehicle Manufacturers, 2014). The trend for vehicles purchased reached its peak in the third quarter of 2014, with 40265 units being purchased. A total of 31473 passenger vehicles were sold in the second quarter of 2015. The trend in the passenger vehicle units purchased can be explained by a strong rand encouraging exportations and an increase in the disposable income of households. The drop in the number of passenger vehicle units purchased can be associated with the domestic political and economic turmoil leading to consumer reluctance to purchase durable goods such as passenger vehicles.

Understanding consumer buying behaviour: According to Ushadevi (2013) the theory of consumer buying behaviour broadly classifies these determinants into economic, sociological and behavioural factors. This study focuses on the economic factors. It is important to highlight the importance of the sociological and behavioural factors that influence consumer behaviour, including the following: family, reference group, opinion leaders, cultural factors, social class and caste, and individual determinants of consumer behaviour, such as age and lifecycles stage, occupation, economic situation, lifestyle, personality, education, belief, attitudes and motivation. For most people, purchasing a car is the second-most important and expensive decision after purchasing a house (Shende, 2014). Kapoor, Dlabay \& Hughes (2010) suggest that this complex exercise consists of four phases: pre-shopping activities, evaluation of alternatives, determination of purchase price and post-purchase activities. Figure 1 below presents the phases of the consumer decision-making process for purchasing personal vehicles.

Figure 1: Phases of the consumer decision-making process for purchasing a personal vehicle

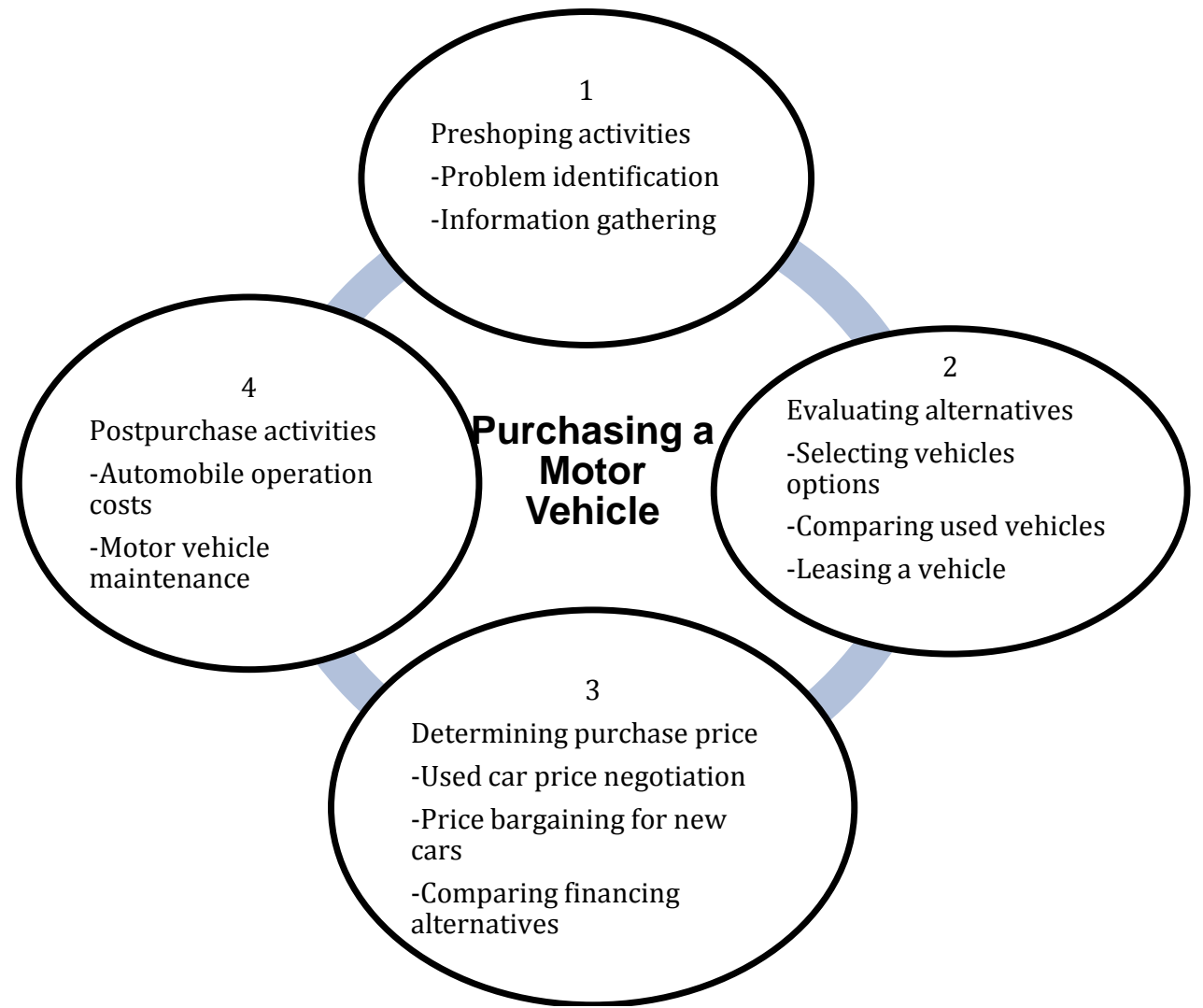

Source: rci.rutgers.edu/ boneill/presentations/FPF-Chapter-6.ppt 
Factors influencing personal vehicle purchasing: Lane \& Potter (2007:1050) suggest that numerous factors influence private car purchasing behaviour. These factors can be categorised as personal, economic and social, regulatory environments, vehicle performance and application. In addition to such objective factors are equally important subjective psychological factors, including attitudes, lifestyle, personality and self-image. This study focused on the economic factors that influence vehicle purchase decisions. In the following sections, interest rates, new vehicle prices, personal disposable income, fuel price and food inflation are discussed in detail.

Interest rate: Mehta (2015) posits that interest rates are one of the most influential factors in relation to consumer purchasing decision. This is mainly because financial contracts for consumer durables consist largely of multiple terms and conditions that include a price interest as well as payment period, which makes it unlikely that the financial costs of different contracts will be exactly the same. Pieterse (2009) indicates that there was a possible negative correlation between prime interest rate movements and new vehicle sales in South Africa. The author considered the steady increase in the prime rate for the period between 2001 and 2003, and again from 2005 to the end of 2008. The corresponding periods recorded a dramatic decline in year new sales growth. However, from 2002 to 2005, the prime rate took a downward turn. In contrast, the year-on-year new vehicle sales growth figures recorded for the related period showed positive growth. It was concluded that higher interest rates ultimately result in a lower demand for motor vehicles and, therefore, fewer applications for motor finance. In this same line, Cokayne (2007) reports that the six consecutive prime rate increases since 2005 had a dramatic negative impact on South African new vehicle sales. Examining the link between interest rate and borrowers' decisions to purchase a passenger vehicle in South Africa, Chisasa \& Dlamini (2013) confirmed the existence of a negative but insignificant relationship between interest rates and passenger vehicle purchases in South Africa. The authors argue that interest rates have no role to play in the decision-making process involved in purchasing a passenger vehicle, implying therefore that by and large, regardless of whether interest rates are high or low, South African consumers will apply for credit to purchase a passenger vehicle.

New Vehicle prices: Investigating the impact of motor vehicle retail prices on consumers' decisions to purchase new motor vehicles in South Africa, Pieterse (2009) found that, out of 194 valid cases considered, approximately two thirds (62.4\%) of the respondents (passenger vehicle consumers) shared the opinion that motor vehicle retail prices were the main impediment to the consumer's decision to apply or not to apply for motor finance. Similarly, Srivastava \& Tiwari (2014) analysed consumer attitudes towards cars manufactured by European, American or Japanese manufacturers. They concluded that country-of-origin effect, brand name and distributor's reputation are significant predictors apart from the pricing of passenger cars. Alper \& Mumcu (2007) investigated the demand for new automobiles in Turkey, using quarterly data on price, quantity, quality, country of origin and product characteristics of the new automobile sales market demand during the period 1996 to 1999. Contrary to Pieterse's (2009) and Srivastava \& Tiwari (2014) assertions that passenger vehicle consumers are price sensitive, the authors observed that in the short run the demand for new automobiles is price-inelastic.

Personal disposable income: According to Mehta (2015), one essential economic factor influencing consumer buying behaviour is income. The author opines that this is mainly because the amount of goods bought by the consumer, as well as the type, differs depending on the wage a consumer earns. He noted that there was a very good chance of a consumer purchasing more luxury goods, such as high-end cars, when he or she has a higher income. Furthermore, the author suggests that there is a positive relationship between income growth and the quality of a car. To explain this further, the author underlines the fact that some studies have demonstrated that income level plays a role in predicting consumers' awareness regarding their attitudes. He also emphasises that in some empirical studies conducted in low income per capita jurisdictions, consumers did not show any improvement in their willingness to spend more on vehicles. Investigating car acquisition and ownership trends in motor vehicle-owning households in Surat, India; Barnerjee, Walker, Deakin \& Kanafani (2010) found household income as the main determinant of the number and size of cars bought by households. Prieto \& Caemmerer (2013) explored factors that influenced car purchasing decisions in major car markets in France. A representative sample of 1967 French households, who bought a new or used car within a year of their study, was considered. The research was based on random utility theory and applied multinomial logit modelling. The findings revealed that income has a positive impact on the decision 
to buy a new car from higher segments and a negative impact on the decision to buy a used car from lower segments.

Fuel price: Barnerjee et al. (2010) examined new vehicle choice in India, principally household choice among motorised vehicle segments. Among the findings, the authors observed that consumers are sensitive to fuel cost and that new vehicles are preferred over used vehicles. In this same line, Biswas et al. (2014) state that Indian consumers are very sensitive to operating costs, as the price of gasoline in India is a large fraction of per capita income. This view supports an earlier study by Menon \& Raj (2012) who found that approximately one-third of car owners in India had diesel vehicles, due to the price difference between gasoline and diesel. McManus (2007) explored the link between fuel prices and sales of motor vehicles and trucks in United States of America. He claims that a significant portion of changes in vehicle prices could be attributed to changes in fuel prices. The author concludes that rising fuel prices lower the prices of automobiles. He argues that the negative impact of rising fuel prices on vehicle prices is greater for less fuel-efficient vehicles than for more fuel-efficient vehicles.

Food inflation: Rangasamy (2010) suggests that food inflation in South Africa has been more persistent than that of other commodities, and could therefore be an important source of underlying inflationary pressures in the economy. Accordingly, an understanding of the interaction of food inflation and passenger vehicle purchase decisions by consumers is important. In this regard, Pieterse (2009) examined the impact of living cost on the decision of consumers whether or not to apply for motor finance. Of the 194 valid cases considered in the study, it was found that $83.5 \%$ of the respondents shared the view that living costs were the main impediment to their decision to apply or not to apply for motor finance in South Africa. It was concluded that the increase in the cost of basic food products had a significant influence on consumers' decision regarding whether or not to finance a motor vehicle in South Africa. Consistent with Pieterse (2009), Bloomberg News (2010) reported that inflation led to slower automotive sales in China. It was argued that car dealers made use of sales discounts of up to $14 \%$ and other incentives to stimulate car sales in the central Chinese city of Zheng Zhou. This was a response to rising prices which reduced buyers' purchasing power. Car dealers feared that a steady increase in the prices of daily necessities would undermine people's expectations of their future financial security, thereby reducing their desire to buy a car.

The place of food inflation in headline inflation: The weight of food products in the consumption basket may not be proportional to the overall impact of food price increases on consumer inflation, considering the fact that products exert both direct and indirect price impacts on overall (headline) inflation (Rangasamy, 2010). The direct impact of an increase in food prices on headline inflation occurs through changes in the prices of food components in the consumption basket, while the indirect impact of food prices occurs through their effect on inflationary expectations, wages and the prices of other components in the CPI. The direct price effects are related to the weight of food in the CPI. Considering the fact that most developing countries have a larger weight for food items in their consumption baskets, the increase of food prices will have a large impact on inflation trends in these countries, in comparison to developed countries. However, it is important to note that within a country, the impact on different segments of the population may differ (Rangasamy, 2010). High food prices are viewed as an incentive for net food producers to produce more food. It was found that whenever food prices are on an upwards trend relative to input prices, farm income will grow, thereby encouraging agricultural investment. On the other hand, rising food prices can present tremendous challenges for poor people, who spend much of their income on food (Johnson, 2008; Von Braun \& Tadesse, 2012). In Afghanistan, for instance, it was found that a $1 \%$ increase in the price of domestic wheat flour is associated with a $0.20 \%$ decline in real monthly per capita food consumption (D'souza \& Jolliffe, 2010).

Durevall, Loening \& Birru (2013) suggest that during the global food crisis, Ethiopia, among other African countries, experienced an unprecedented increase in inflation, which was among the highest in Africa. Monthly data over the past decade were used, and models of inflation were estimated to identify the importance of the factors contributing to CPI inflation and three of its major components: cereal prices, food prices and non-food prices. The results showed that inflation in Ethiopia is strongly associated with the dominant role of agriculture and food in the economy. In fact, Ethiopia's inflation was practically synonymous with food price inflation during the study period. It was found that in the long run, food prices seem to be determined in the external sector, in other words, the exchange rate and international food prices explain the 
evolution of Ethiopia's food prices. In the short run, domestic agricultural supply shocks, as well as interseasonal fluctuations, which are probably induced by expectations regarding future harvests, cause large deviations from the long-run relationship between domestic and foreign food prices. Figure 2 below illustrates the impact of food price increases on consumer inflation

Figure 2: Impact of food price increases on consumer inflation

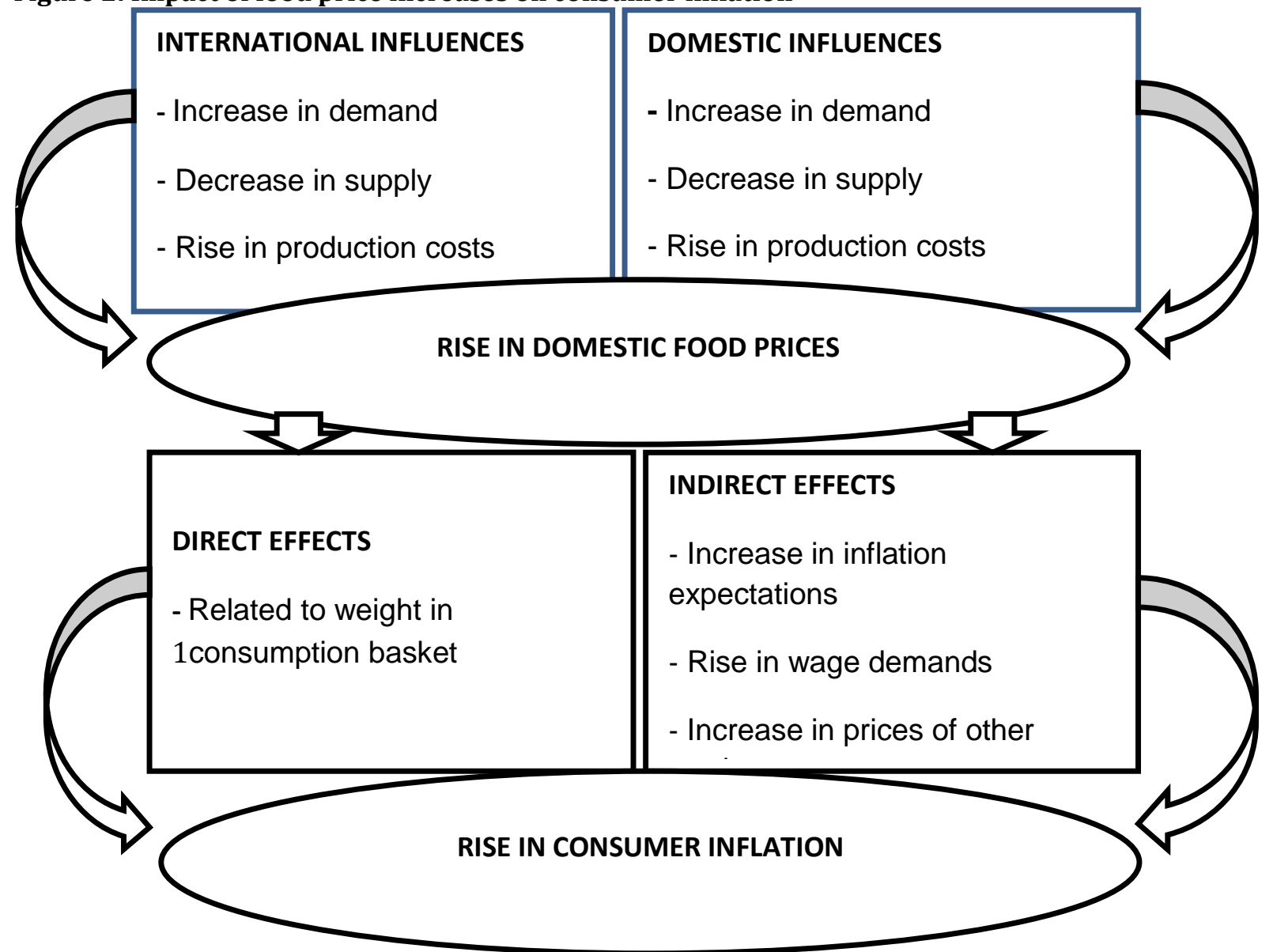

Source: Rangasamy (2010)

The trend in the contribution of food inflation to headline inflation in South Africa suggests that during the 1980s, the contribution of food inflation to headline inflation was proportional to its weight in the CPI basket. This weight represents the consumer household expenditure during a specific period (National Agricultural Marketing Council, 2012). Over the last two decades, this contribution has shown a considerable increase (Rangasamy, 2010). Although it has been noted that the increasing inflation rate in South Africa is mostly the result of an increase in food price inflation, this was not always the case. There is evidence that between 1998 and 1999, when CPI food was growing at a relatively constant rate, the overall inflation rate was declining. Nevertheless, between the end of 1999 and the middle of 2000, and again from the middle of July 2001, there was a clear indication that the increase in CPI for food had preceded an increase in the overall rate of inflation (National Agricultural Marketing Council, 2004).

Between 2002 and 2008, the contribution of food products to headline inflation increased its weight in the consumption basket by approximately $1.4 \%$ (Rangasamy, 2010). In 2012, the weight of the food category in the CPI was 14.27, while the weight of food and non-alcoholic beverages was 15.68. The average food and non-alcoholic beverages CPI for $2012 \mathrm{kept}$ on increasing in comparison to previous years. It was recorded at an average of 127.4 index points, seven points higher than the 118.93 index points for 2011. The CPI rate for food and non-alcoholic beverages averaged $7.2 \%$ for 2012 , showing that consumers paid $7.2 \%$ more for food 
and non-alcoholic beverages in 2012 than they paid in 2011 (National Agricultural Marketing Council, 2012). Comparing the food and non-alcoholic CPI to the headline CPI provides an indication of the impact of the food and non-alcoholic CPI on the headline CPI. During 2012, the CPI for food and non-alcoholic beverages was higher than the headline CPI rate. This was similar to 2011, when the CPI rate for food and non-alcoholic beverages exceeded the headline CPI rate. South Africa's official food price inflation rate (year on year) in December 2013 was 3.5\%, whereas the headline inflation rate (CPI) was 5.4\%. Table 1 below presents the annual average rate of headline and food inflation in South Africa from 2008 to 2013.

Table 1: The annual average rate of headline and food inflation in South Africa

\begin{tabular}{|c|c|c|c|c|c|c|}
\hline & 2008 & 2009 & 2010 & 2011 & 2012 & 2013 \\
\hline $\begin{array}{l}\text { Headline } \\
\text { Inflation }\end{array}$ & 10.04 & 7.1 & 4.3 & 5.0 & 5.6 & 5.8 \\
\hline $\begin{array}{l}\text { Food } \\
\text { inflation }\end{array}$ & 13.85 & 9.4 & 0.8 & 7.3 & 7.4 & 5.9 \\
\hline
\end{tabular}

Source: Stats SA (2014)

The Impact of the increase in food prices on consumer purchase decisions: It has been demonstrated that consumers react to pressures, including high prices at the petrol pump, economic uncertainty and escalating food costs (McCarty, 2011). Increasing prices affect household consumption patterns in two ways: first, through the percentage of the household's expenditure dedicated to consumption, and second, through the consumer basket mix of goods that are regularly purchased. Indeed, households that allocate a higher percentage of their total income to food experience higher food inflation, as an increase in the price of a consumer basket will mean more money being spent on consumption, in comparison to those households whose percentage of money spent on food is small (Capehart \& Richardson, 2008; McGranahan, 2008). In recent years, there has been a visible rise in prices globally, particularly for food, which makes up a large part of the budget of low-income households (Levell \& Oldfield, 2011). These increasing prices lower the purchasing power of a given nominal income and further affect the expenditure decisions of households (United Nations, 2012).

Rising food prices lead to distress, food riots and declining purchasing power, as well as aggravating chronic poverty and enhancing inequality (Food and Agricultural Organisation, 2008; High Level Panel of Experts on Food Security and Nutrition, 2011). The higher the prices, the stronger the welfare consequences for consumers (High Level Panel of Experts on Food Security and Nutrition, 2011). The short-term responses may include a reduction in food consumption and an increase in labour supply through piece jobs and dissaving (World Bank, 2008). Furthermore, increasing prices have an uneven impact across population groups and prompt different responses (Wodon \& Zaman, 2008). The poor respond by limiting food consumption and adopting less balanced diets, which have short- and long-term negative health consequences. The non-poor do not necessarily reduce food consumption, but will spend less on durables. The fact that the poor spend a greater part of their income on food makes them worse off than the non-poor when there are food price increases (Regmi, Deepak, Seale \& Bernstein, 2001; United Nations, 2012). A survey conducted in the USA on the impact of rising food prices on consumers' spending found that in-home food products were not the only areas of spending that were affected. Some other areas where respondents would change their spending were also mentioned. These areas included dining out (64\%), buying new clothes (55\%), spending on snack food (45\%), paying for recreation and entertainment (44\%) and going on vacation (39\%) (Nielsen, 2013).

The Bureau of Food and Agriculture Policy, which is a unit at the University of Pretoria, presented, in their 2009 annual baseline presentation, an analysis of the impact of food inflation during the 2007-2009 period on different consumer groups in South African society. In their findings, it was highlighted that the poorest consumers had to spend $12.8 \%$ more of their annual income in $2007 / 08$ to buy the same food basket, while the wealthiest consumers had to pay an additional R1 840 per year for the same food basket. However, the latter was only $0.7 \%$ of their annual income, which therefore had a much smaller impact than in the case of poor consumer groups. In an empirical study on the NCA of South Africa and the motor finance sector, it was found that an increase in the price of basic food in South Africa was one of the factors that also influenced consumers' vehicle purchase decisions (Pieterse, 2009). In fact, based on the primary data collected via 
questionnaires from both consumers and credit providers in the country, it was found that the cost of basic foods had a significant influence on consumers' decisions to or not to apply for motor vehicle finance (Pieterse, 2009).

\section{Methodology}

Data: Secondary data of a time series nature spanning January 2008 to August 2015 were used for this study. The principal sources of secondary data were as follows: data for the passenger vehicle quarterly sales units (VP) were obtained from the National Association of Automobile Manufacturer of South Africa (NAAMSA). The food inflation (FI) figures proxied by the food and non-alcoholic beverages index were obtained from Statistics South Africa (Stats SA). Disposable household income data were obtained from the South African Reserve Bank (SARB). Passenger vehicle unit price (P) figures proxied by the producer price index for manufacturer were obtained from the SARB. Interest rate (IR) figures proxied by the prime overdraft rates were obtained from the SARB. Lastly, fuel price (FP) figures proxied by the price of petrol per cubic meter were acquired from the South African petroleum Association. All the sources of data stated herein are public data domains, duly audited thus the data used for this study is deemed valid and reliable.

Unit root test: The data were subjected to unit root tests using the augmented dickey-fuller (ADF) Schwarz info criterion and the Phillip-Perron (PP) test, in order to test stationarity.

Cointegration Technique: To test the presence of a long run relationship among the variables, the Johansen and Juselius (1990) cointegration method was used. The Johansen and Juselius test was performed on variables which were found to be integrated of order 1. The Johansen test has two types of test of cointegration. The first is the "trace" test, which has the null hypothesis that the number of cointegrating vectors are not of full rank and thus: $r^{*}=r<k$ with an alternative of $r=k$. This differs from the Max Eigen value approach which tests where the alternative is specified as $r=r^{*}+1$

Vector error correction model: The effect of food inflation on consumer purchase behaviour can be perceived over the short- and long-term. Considering the important place of food in headline inflation in South Africa, the vector error correction model (VECM), was applied in order to account for the dynamics of the short- and long-run relationship between food inflation and vehicle purchases. The VECM model can be specified as:

where

$$
\Delta \mathrm{X}_{\mathrm{t}}=\mu+\Phi \mathrm{D}_{\mathrm{t}}+\Pi \mathrm{X}_{\mathrm{t}-\mathrm{p}}+\Gamma_{\mathrm{p}-1} \Delta \mathrm{X}_{\mathrm{t}-\mathrm{p}+1}+\cdots+\Gamma_{1} \Delta \mathrm{X}_{\mathrm{t}-1}+\varepsilon_{\mathrm{t}}, \quad \mathrm{t}=1, \ldots, \mathrm{T}
$$

$$
\Gamma_{\mathrm{i}}=\Pi_{1}+\cdots+\Pi_{\mathrm{i}}-\mathrm{I}, \quad \mathrm{i}=1, \ldots, \mathrm{p}-1
$$

dictates the long- and short-run dynamics. Therefore, $\Pi=\alpha \beta^{\prime}$, where $\Pi$ dictates the number of cointegrating relationships, $\alpha$ is the speed of adjustment parameters and $\beta$ is the cointegrating vectors.

In this study, the dynamic relationship between food inflation and vehicle purchases was the main focus. This relationship can therefore be seen as (excluding the external regressors):

$\left[\begin{array}{l}\Delta x_{t} \\ \Delta y_{t}\end{array}\right]=\left[\begin{array}{l}\alpha_{1} \\ \alpha_{2}\end{array}\right][1-\beta] \cdot\left[\begin{array}{l}x_{t-1} \\ y_{t-1}\end{array}\right]+\left[\begin{array}{l}\varepsilon_{1, t} \\ \varepsilon_{2, t}\end{array}\right]$

Granger causality estimation model: A pairwise Granger causality test was conducted to examine the transmission mechanism between food inflation and vehicle purchases and other predictor variables of vehicle purchases. Therefore, in order to determine the nexus between food inflation and vehicle purchases, the Engle and Granger (1987) two-step procedure was applied, as specified in equations 2 and 3 below:

$\mathrm{VP}_{\mathrm{t}}$

$$
=\mathrm{a}+\sum_{j=1}^{N} n_{j} F I_{t-j}+\sum_{j=1}^{N} y_{j} V P_{t-j}+\mu_{t}
$$

$\mathrm{FI}_{\mathrm{t}}$

$$
=\sum_{j=1}^{N} \alpha_{j} V P_{t-j}+\sum_{j=1}^{N} \beta_{j} F I_{t-j}+\mu_{t}
$$

Where: VP = Vehicle purchases 
FI $\quad=$ Food inflation

$\mathrm{t} \quad=$ time period $(01 / 2008-08 / 2015)$.

The error terms $\mu$ are assumed to be uncorrelated.

The null hypotheses to be tested were:

$\mathrm{H}_{1}: \mathrm{n}_{\mathrm{j}}=0, \mathrm{j}=1,2,3 \ldots \ldots \ldots . . \mathrm{N}$ meaning that food inflation does not Granger-cause vehicle purchases (VP).

$\mathrm{H}_{2}: \alpha_{\mathrm{j}}=0, \mathrm{j}=1,2,3 \ldots \ldots . . \mathrm{N}$ meaning that VP does not Granger-cause food inflation.

If the first hypothesis is rejected, it means that food inflation Granger-causes vehicle purchases. Rejection of the second hypothesis would show that the causality runs from vehicle purchases to food inflation. If none of the hypothesis is rejected, it would mean that food inflation does not Granger-cause vehicle purchases and vehicle purchases do not Granger-cause food inflation, indicating that the two variables are independent of each other. If both hypotheses are rejected, it means there is bi-directional causality between food inflation and vehicle purchases. Pairwise Granger causality tests among factors influencing vehicle purchases were also performed.

\section{Results and Discussion}

Unit Root results: Table 2 below, reports conflicting unit root test results for stationarity. Since the PP test is non-parametric in nature, it will be the preferred method for the unit root test. Household disposable income and new vehicle prices are the only variables that the test confirms to be stationary. For the rest of the variables, the p-values at a $10 \%$ significance value suggest that the null of a unit root cannot be rejected. These results paved way for an examination of the presence of a long-run relationship between food inflation and vehicle purchases using cointegration tests.

Table 2: Unit root test results

\begin{tabular}{|c|c|c|c|c|c|c|c|c|}
\hline \multirow[t]{2}{*}{ Variable } & \multicolumn{4}{|c|}{ Augmented Dickey-Fuller } & \multicolumn{4}{|c|}{ Phillips-Perron } \\
\hline & $\begin{array}{l}\text { Level with } \\
\text { intercept } \\
\text { (p-value) }\end{array}$ & $\begin{array}{l}\text { Order of } \\
\text { integration }\end{array}$ & $\begin{array}{l}\mathbf{1}^{\text {st }} \\
\text { difference } \\
\text { with } \\
\text { intercept }\end{array}$ & $\begin{array}{l}\text { Order of } \\
\text { integration }\end{array}$ & $\begin{array}{l}\text { Level with } \\
\text { intercept }\end{array}$ & $\begin{array}{l}\text { Order of } \\
\text { integration }\end{array}$ & $\begin{array}{l}1^{\text {st }} \\
\text { difference } \\
\text { with } \\
\text { intercept }\end{array}$ & $\begin{array}{l}\text { Order of } \\
\text { integration }\end{array}$ \\
\hline VP & -0.4042 & $\mathrm{I}(1)$ & $-3.2380^{* *}$ & $\mathrm{I}(0)$ & $-3.4873^{*}$ & $\mathrm{I}(0)$ & - & $\mathrm{I}(0)$ \\
\hline FI & $-4.1272^{* *}$ & $\mathrm{I}(0)$ & - & $\mathrm{I}(0)$ & -1.7599 & $\mathrm{I}(1)$ & $-4.6474^{* * *}$ & $\mathrm{I}(0)$ \\
\hline $\mathrm{FP}$ & -0.7692 & $\mathrm{I}(1)$ & $-4.1203^{* *}$ & $\mathrm{I}(0)$ & -2.1128 & $\mathrm{I}(1)$ & $-14.9974^{* * *}$ & $\mathrm{I}(0)$ \\
\hline IR & -1.5560 & $\mathrm{I}(1)$ & $-5.0084^{* * *}$ & $\mathrm{I}(0)$ & -1.0389 & $\mathrm{I}(1)$ & $-3.6638^{* * *}$ & $\mathrm{I}(0)$ \\
\hline $\mathrm{P}$ & -2.2120 & $\mathrm{I}(1)$ & - & - & -2.3049 & $\mathrm{I}(1)$ & - & - \\
\hline
\end{tabular}

Note: ${ }^{* *},{ }^{* *}$ and ${ }^{*}$ denote significance at 1,5 and $10 \%$ levels, respectively (Source: R Statistics)

Cointegration Results: The Johansen trace cointegration test illustrates the existence of four integrating equations at the 95\% (p-value=0.05) confidence level suggesting therefore that vehicle purchases, food inflation, fuel price, interest rate, household disposable income and new vehicle price are cointegrated in the long run. Both the Trace Statistic (Table 3) and the Max-Eigen Statistic (Table 4) are higher than the Eigenvalue. This result confirms that the variables under review are cointegrated in the long run, hence a long-run equilibrium exists between them.

Table 3: Trace Statistics

\begin{tabular}{lllll}
\hline $\begin{array}{l}\text { Unrestricted Cointegration Rank Test } \\
\text { Trace } \\
\text { Hypothesized No. of CE(s) }\end{array}$ & Eigenvalue & $\begin{array}{l}\text { Trace } \\
\text { Statistic }\end{array}$ & $\begin{array}{l}\text { Critical Value } \\
\mathbf{( 0 . 0 5 )}\end{array}$ & Prob.** \\
\hline None* & 0.989798 & 293.092 & 95.75366 & 0 \\
At most $1 *$ & 0.950881 & 169.2914 & 69.81889 & 0 \\
At most $2 *$ & 0.872924 & 87.92645 & 47.85613 & 0 \\
At most $3 *$ & 0.565989 & 32.22625 & 29.79707 & 0.0258 \\
At most 4 & 0.293434 & 9.68977 & 15.49471 & 0.3054 \\
At most 5 & 0.011475 & 0.311608 & 3.841466 & 0.5767 \\
Trace test indicates 4 cointegrating equations at the 0.05 level & & \\
\hline
\end{tabular}




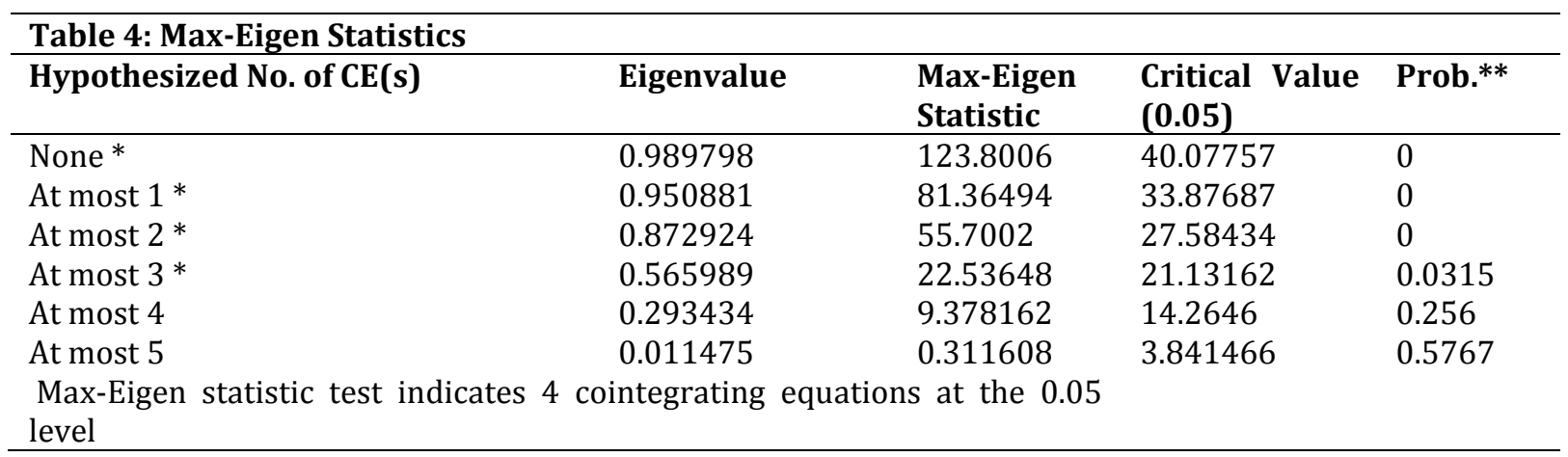

VECM long-run relationship: Results of the VECM presented in Table 5 below show that there is a negative and insignificant long-run relationship between food inflation and vehicle purchases. Similarly, Chifurira et al. (2014) found that there is a long-run relationship between new vehicle sales and inflation in South Africa. This confirms the view that passenger vehicles are purchased by high living standards measures (LSM) groups within a socio-economic group. Food inflation will have less to no impact on vehicle purchases by this category of consumers, considering the fact that food expenditure occupies a relatively small proportion of their disposable income. Furthermore, the test showed that the long-run relationship is dominated by the effect of vehicle purchase in the previous period. Given that the long-run relationship seems to be solely dependent on past values of the dependent series, a closer study into the short-run dynamics is required. The $\alpha$ parameter in the VECM formulation is representative of the short-run deviations of the long run.

Table 5: Estimated long run relationship

\begin{tabular}{lll}
\hline Cointegration Eq: & ColntEq1 & \\
\hline VP(-1) & 1 & \\
& -278.679 & \\
C & {$[0.70727]$} & \\
Error Correction & -30449.05 & $\mathrm{D}(\mathrm{FI})$ \\
CointEq1 & $\mathrm{D}(\mathrm{VP})$ & $6.30 \mathrm{E}-05$ \\
& 0.885801 & -0.00016 \\
$\mathrm{D}(\mathrm{VP}(-1))$ & -0.21425 & {$[0.39778]$} \\
& {$[-4.13441]$} & -0.000123 \\
$\mathrm{D}(\mathrm{VP}(-2))$ & 0.287738 & -0.00019 \\
& -0.25698 & {$[-0.64468]$} \\
$\mathrm{D}(\mathrm{FI}(-1))$ & {$[1.11967]$} & -0.000149 \\
& 1.004455 & -0.00021 \\
$\mathrm{D}(\mathrm{FI}(-2))$ & -0.28757 & {$[-0.70237]$} \\
& {$[3.49292]$} & 0.038323 \\
$\mathrm{C}$ & 295.7536 & -0.22395 \\
& -302.798 & {$[0.17113]$} \\
& {$[0.97674]$} & -0.188402 \\
FP & 140.7593 & -0.19868 \\
& -268.638 & {$[-0.94826]$} \\
$\mathrm{I}$ & {$[0.52397]$} & 8.738258 \\
& -41018.14 & -11.2117 \\
& -15159.4 & {$[0.77939]$} \\
& {$[-2.70579$} & -0.003187 \\
& 26.01532 & -0.00536 \\
& -7.24858 & {$[-0.59452]$} \\
& {$[3.58902]$} & $-5.30 \mathrm{E}-06$ \\
& 0.034039 & $-1.20 \mathrm{E}-05$ \\
& -0.0169 & {$[-0.42418]$} \\
& {$[2.01409]$} &
\end{tabular}




\begin{tabular}{lll} 
IR & 1219.319 & -0.806898 \\
& -670.806 & -0.49612 \\
P & {$[1.81769]$} & {$[-1.62641]$} \\
& -330.0596 & 0.514142 \\
& -228.753 & -0.16918 \\
R-squared & {$[-1.44286]$} & {$[3.03896]$} \\
Adj. R-squared & 0.773917 & 0.59703 \\
F-statistic & 0.654226 & 0.383692 \\
F-statistic & 2198.06 & 1.625659 \\
Log likelihood & 6.465952 & 2.798524 \\
S.D. dependent & -239.8398 & -45.18558 \\
\hline Source: R-Statistics & 3738.033 & 2.070764 \\
\hline
\end{tabular}

Source: R-Statistics

The VECM results showed that there is no relationship between vehicle purchases and food inflation in the short run. This means that an increase or decrease of food inflation in the short run will have no effect over consumers' decision to purchase passenger vehicles. This is similar to the view by Chisasa \& Dlamini (2013), which suggests that economic factors do not play a significant role in the passenger vehicle purchase decision. The authors submitted that the cost of credit and, hence the total cost of acquiring the vehicle, are not a significant factor in the decision-making process, advocating for psycho-social factors to be more determinant regarding vehicle purchase decisions in South Africa. Furthermore, the results of the VECM showed the existence of a positive and significant short run relationship between vehicle purchases and fuel price at $1 \%$ level of significance, vehicle purchases and interest rate at $10 \%$ level of significance.

Table 6: VECM short run results

\begin{tabular}{lllll}
\hline D(VP) & Coefficient & Std. Error & t-Statistic & Prob. \\
\hline CointEq1 & -0.885801 & 0.214251 & -4.134414 & $0.0002^{* * *}$ \\
D(VP(-1)) & 0.287738 & 0.256984 & 1.119673 & 0.2707 \\
D(VP(-2)) & 1.004455 & 0.287569 & 3.492922 & $0.0013^{* * *}$ \\
D(FI(-1)) & 295.7536 & 302.7977 & 0.976737 & 0.3356 \\
D(FI(-2)) & 140.7593 & 268.6383 & .523974 & 0.6037 \\
C & -41018.14 & 15159.39 & -2.705791 & $0.0106^{* * *}$ \\
FP & 26.01532 & 7.248582 & 3.589022 & $0.001^{* * *}$ \\
I & 0.034039 & 0.0169 & 2.014086 & $0.052^{* *}$ \\
IR & 1219.319 & 670.8063 & 1.817692 & $0.0779^{*}$ \\
P & -330.0596 & 228.7534 & -1.442862 & 0.1582 \\
\hline SOurce: & & & & \\
\hline
\end{tabular}

Source: R-Statistics

Granger causality test results: The results of the Granger causality test as per Table 7 below show that there is no causal effect running from food inflation to vehicle purchases or a causal effect running from vehicle purchases to food inflation. The two variables were found to be independent from each other. This is in contrast with the study by Chifurira et al. (2014), which found in South Africa, the existence of a one-way causal effect (unidirectional causality) running from new vehicle sales at $5 \%$ level of significance. Considering the fact that food inflation in South Africa was found to affect mostly the poor range of the population and having a smaller to negligible impact on the wealthiest consumers' annual income, this corroborates more the view that an increase in the price of food products will not cause any impact on the purchase of passenger vehicles in South Africa.

Table 7: VEC Granger causality/Block Exogeneity

\begin{tabular}{llllll}
\hline Null Hypothesis: & Obs & Lags & Chisq. & Prob. & Result \\
\hline D(FI) does not cause D(VP) & 28 & 2 & 1.448641 & 0.4847 & $H_{-} 0$ is not rejected \\
D(VP) does not cause D(FI) & 28 & 2 & 1.107052 & 0.5749 & $H_{-} 0$ is not rejected \\
\hline
\end{tabular}




\section{Conclusion}

Inflation poses serious economic challenges to businesses and consumers. This is mainly due to its adverse effect on the value of consumer buying power, social instability and reduction of confidence in the currency (Ashraf, Gershman \& Howitt, 2013). Considering the fact that food inflation in South Africa is viewed as an important source of underlying inflationary pressures in the economy due to its persistence beyond that of other commodities (Rangasamy, 2010), the present study is of considerable value by explaining the relationship between food inflation and consumer purchases of passenger vehicles. The results of the present study suggest that food inflation and vehicle purchases are cointegrated in the long run, hence a long-run equilibrium exist between the variables but have no relationship with each other in the short run. Similarly, Chifurira et al. (2014) suggest the existence of a cointegration in the long-run between car sales and inflation in South Africa. However, in contrast to the present study, the authors only considered inflation as a predictor of car sales, while this study considered five economic predictors of vehicle purchases, including food inflation. In Addition, the present study finds a positive and significant short run relationship between vehicle purchases and fuel price in South Africa. Similarly, Menon \& Raj (2012) argues that approximately one-third of car owners in India had diesel vehicles, due to the price difference between gasoline and diesel, thereby presenting the significant impact of fuel price on car purchases in India. Furthermore, the results of the present study reveal no causal effect running from food inflation to vehicle purchases or a causal effect running from vehicle purchases to food inflation. The two variables are independent from each other. In conclusion, South African will purchase their new passenger vehicles despite hikes in food price products. This is due to the fact that passenger vehicle purchases are the privileges of individuals pertaining in a higher socio-economic level where food expenditure occupies a small proportion of their disposable income. Hence, food inflation will have no impact on vehicle purchases in South Africa.

Recommendations: In light of the long-run relationship between food inflation and vehicle purchases that this study has demonstrated, stakeholders in the motor industry should be mindful of possible changes in consumer spending patterns as inflation continues to spiral. Such consumer responses to inflation variability should be incorporated when formulating policy directed at marketing, production, sales and firm profitability. Furthermore, Given that the long-run relationship revealed in this study seems to be highly dependent on past values of vehicle purchases, a closer study into the link between psycho-social factors and the passenger vehicle purchase decision in South Africa is recommended. This is similar to the suggestion by (Chisasa \& Dlamini, 2013).

Acknowledgements: This paper is based on a master's degree research project by the first author, titled: An empirical analysis of the relationship between food inflation and passenger vehicle purchase decisions in South Africa.

\section{References}

Alper, C. E. \& Mumcu, A. (2007). Interaction between price, quality and control of origin when estimating automobile demand: The case of Turkey. Applied Economics, 39, 1789-1796.

Ashraf, Q., Gershman, B. \& Howitt, P. (2013). How inflation affects macroeconomics performance: An agentbased computational investigation. NBER Working Paper no. 18225. Harvard: Harvard University.

Asia-Pacific Economic Cooperation (APEC). (2012). Effective automotive policies and barriers to growth: Joint Industry Report for Apec Automotive Dialogue. Available from http://www.apec.org/Groups/Committee-on-Trade-andInvestment/ /media/Files/Groups/AD/00_cti_ad_autopolicy.ashx (Accessed on 8 August 2014).

Banerjee, S. (2010). Study on consumer buying behavior during purchase of a second car. Journal of Marketing \& Communication, 6(2), 4-13.

Biswas, A., Mukherjee, A. \& Roy, M. (2014). Leveraging factors for consumers' car purchase decisions: A study in an emerging economy. Journal of Management Policies and Practices, 2(2), 99-111.

Bloomberg News. (2010). Inflation leads to slower auto sales in Chinahttp://www.bloomberg.com/bw/magazine/content/10_33/b4191021627591.htm (Accessed on 25 February 2015). 
Capehart, T. \& Richardson, J. (2008). Food price inflation: Causes and impacts. Available from http://asserts.opencrs.com/rpts/R22859-20080410.pdf (Accessed on 18 October 2015).

Cheng, H. K., Sims, R. R. \& Teegen, H. (1997). To purchase or to pirate software: An empirical study. Journal of Management Information Systems, 13(4), 49-60.

Chifurira, R., Mudhombo, I., Chikobvu, M. \& Dubihlela, D. (2014). The impact of inflation on the automobile sales in South Africa. Mediterranean Journal of Social Sciences, 5(7), 200-206.

Chisasa, J. \& Dlamini, W. (2013). An empirical analysis of the interest rate-vehicle purchase decision nexus in South Africa. International Business \& Economics Research Journal, 12(5), 477-488.

Cokayne, R. (2007). Credit Act props up car sales. Business Report, 3 October. Available from http://www.busrep.co.za/index.php?fSectionId=552\&fArticleId=4061825 (Accessed on 23 December 2014).

Dubihlela, D. \& Sekhampu, T. J. (2014). The impact of price changes on demand among poor households in a South African township. International Business \& Economics Research Journal, 13(3), 463-474.

D'souza, A. \& Jolliffe, D. (2010). Rising food prices and coping strategies: Household-level evidence from Afghanistan. Policy Research Working Paper, 2(24), pp.5466

Durevall, D., Loening, J. L. \& Birru, A. Y. (2013). Inflation dynamics and food prices in Ethiopia. Journal of Development Economics, 104(2013), 89-106.

Engle, R. F. \& Granger, C. W. J. (1987). Co-integration and error correction: Estimation and testing. Econometrica, 55(2), 251-276.

Food and Agricultural Organisation (FAO). (2008). Nutrition and consumer protection. Rome.

High Level Panel of Experts on Food Security and Nutrition (HLPE). (2011). Price volatility and food security: A report by the High Level Panel of Experts on Food Security and Nutrition of the Committee on World Food Security. Rome.

International Organization of Motor Vehicle Manufacturers (OICA). (2014). Vehicles sales statistics. Available from http://www.oica.net (Accessed on 5 August 2014).

Johansen, S. \& Juselius, K. (1990). Maximum likelihood estimation and inference on cointegration: With application to the demand for money. Oxford Bulletin of Economics and Statistics, 52, 169-210.

Johnson, K. H. (2008). Food price inflation: Explanation and policy implications. CGS Working Paper. New York, NY: Council on Foreign Relations.

Kapoor, J. R., Dlabay, L. R. \& Hughes, R. J. (2010). Focus on personal finance: An active approach to help you develop successful financial skills. McGraw-Hill.

Lane, B. \& Potter, S. (2007). The adoption of cleaner vehicles in the UK: Exploring the consumer attitudeaction gap. Journal of Cleaner Production, 15(11/12), 1085-1092.

Levell, P. \& Oldfield, Z. (2011). The spending patterns and inflation experience of low-income households over the past decade. London: Institute for Fiscal Studies.

Makatouni, A. (2002). What motivates consumers to buy organic food in the UK? Results from a qualitative study. British Food Journal, 104(3), 345-352.

McCarty, R. (2011). Economics and food choices: Consumer response to food price inflation. Analysis \& strategy. Available fromhttp://www.beefissuesquarterly.com/beefissuesquarterly.aspx?id=4031 (Accessed on 6 April 2015).

McGowan, D. (1984). Consumer economics. Second edition. Mishawaka, USA: Allyn \& Bacon.

McGranahan, L. (2008). Food inflation and the consumption patterns of the United States households. Chicago, IL: Federal Reserve Bank.

McManus, W. (2007). The link between gasoline prices and vehicle sales: Economic theory trumps conventional Detroit wisdom. Business Economics, 1, 53-60.

Mehta, H. (2015). Factors affecting consumer purchasing decision in Kenya's motor industry: Case of Toyota Kenya customers. Unpublished MBA dissertation. Kenya: United States International University Africa.

Menon, B. \& Raj, J. V. P. (2012). Dominant mean percentage score factors of the consumer purchase behaviour of passenger cars. International Journal of Research in IT and Management, 2(5), 13-36.

Muhammad, F., Hussin, M. Y. M. \& Razak, A. A. (2012). Automobile sales and macroeconomic variables: A pooled mean group analysis for ASEAN countries. IOSR Journal of Business and Management, 2(1), $15-21$. 
Muhammad, F., Hussin, M. Y. M., Razak, A. A., Rambeli, N. \& Tha, G. P. (2013). The Relationship between Macroeconomic Variables and Passenger Vehicle Sales in Malaysia. Business and Economic Research, $3(2), 123-124$.

Munchanda, P., Ansari, A. \& Gupta, S. (1999). The shopping basket: A model for multicategory purchase incidence decisions. Marketing Science, 18(2), 95-114.

National Agricultural Marketing Council (NAMC). (2004). The government responding to the food price crisis. Available from http://www.namc.co.za/upload/food_price_monitoring/FPM\%20Report\%202004_02_Intro.pdf (Accessed on 3 March 2015).

National Agricultural Marketing Council (NAMC). (2012). The South African Food Cost Review 2012. Pretoria.

Nielsen. (2013). 85\% of global online respondents say rising food prices will impact their groceries choices. Available from http://www.nielsen.com/us/en/press-room/2013/nielsen-85-of-global-onlinerespondents-say-rising-food-prices.html (Accessed on 21 June 2015).

Pieterse, H. C. (2009). The National Credit Act of South Africa and the motor finance sector. Unpublished master's thesis. Pretoria: University of South Africa.

Prieto, M. \& Caemmerer, B. (2013). Automobile retail and services chair. Available from http://www.emeraldinsight.com/0959-0552.htm (Accessed on 18 August 2014).

Rangasamy, L. (2010). Food inflation in South Africa: Some implications for economic policy. South African Journal of Economics, 79(2), 184-201.

Regmi, A., Deepak, J., Seale, J. L. \& Bernstein, J. (2001). Cross-country analysis of food consumption patterns. New York, NY: USDA.

Rimal, A. P., Moon, W. \& Balasubramanian, S. (2005). Agro-biotechnology and organic food purchase in the United Kingdom. British Food Journal, 107(2), 84-97.

Shende, V. (2014). Analysis of research in consumer behavior of automobile passenger car customer. International Journal of Scientific and Research Publications, 4(2), 12-15.

Srivastava, M. K. \& Tiwari, A. K. (2014). A study of behavior of Maruti SX4 and Honda City customers in Jaipur. Available from https://www.researchgate.net/publication/272705212 A_Study_of_Behaviour_of_Maruti_SX4_and_Honda_City_Customers_in_Jaipur (Accessed on 20/05/2014).

United Nations (UN). (2012). Global economic outlook. Prospectus for the World Economy, 2012-2013. California.

Statistics South Africa. (2014). The annual average rate of headline and food inflation in South Africa. Available from: www.statssa.gov.za (Accessed on 04/08/2014)

Ushadevi, K. N. (2013). Consumer behaviour: A theoretical framework. Available from www.shodhganga.inflibnet.ac.in/bitstream/10603/7102/12/12_chapter\%202.pdf (Accessed on 16 July 2015).

Von Braun, J. \& Tadesse, G. (2012). Global food price volatility and spikes: An overview of costs, causes and solutions. ZEF-Discussion Papers on Development Policy no. 161. Bonn: Centre for Development Research.

Wodon, Q. \& Zaman, H. (2008). Rising food prices in sub-Saharan Africa: Poverty impact and policy responses. World Bank Research Observer, 25(1), 157-176.

World Bank. (2008). World development indicators. Poverty data supplement to World Development Indicators. Washington, DC.

Zide, S. (2012). An analysis of the demand for new passenger vehicles in South Africa (19952005).Unpublished master's thesis. Vanderbijlpark: North-West University. 